\title{
INTEGRASI PENGUATAN PENDIDIKAN KARAKTER KEDISIPLINAN DI SEKOLAH DASAR DALAM PEMBELAJARAN BERBASIS E-LEARNING
}

\author{
Muhammad Ragil Kurniawan, Sugeng Rianto \\ Universitas Ahmad Dahlan, Jl. Ki Ageng Pemanahan No. 19 Yogyakarta, \\ Correspondence Author: ragil.kurniawan@pgsd.uad.ac.id
}

\begin{abstract}
Abstrak
Era digital sudah merambah di berbagai lini kehidupan oleh karenanya pendidikan juga layak untuk melakukan akselerasi pengembangan inovasi pembelajaran berbasisi internet dengan mengutamakan pendidikan karakter. Pendekatan yang digunakan dalam penelitian ini adalah Analisis konten. Adapun Rumusan masalah dalam penelitian ini adalah: a) Bagaimana ragam fasilitas e-learning yang dapat digunakan dalam pembelajaran jarak jauh di sekolah dasar, b) Bagaimana ragam aktivitas penguatan pendidikan karakter di sekolah dasar yang dapat dimasukkan dalam berbagai fasilitas yang ada dalam elearning. c) Apa saja ragam nilai-nilai karakter kedisiplinan yang dapat diimplementasikan dalam elearning Sekolah Dasar. Penelitian ini merupakan penelitian analisis konten. Objek penelitian ini adalah aplikasi pembelajaran berbasis learning management system (LMS) google classroom dan edmodo. Metode pengambilan data yang digunakan adalah dokumentasi dan instrumen analisis kritis. Sumber data berupa hasil hasil analisis dan hasil FGD dengan para ahli. Data hasil penelitian diolah dengan menggunakan data kualitatif. Terdapat banyak kesamaan menu pada LMS GC dan Edmodo. Beberapa menu yang terdapat di kedua LMS tersebut adalah menu pemberian materi, menu penugasan, kuis, serta fasilitas diskusi. Berdasarkan ragam fasilitas e-learning untuk penguatan pendidikan karakter ini dapat disimpulkan bahwa terdapat dua karakter utama penguatan pendidikan karakter kedisiplinan melalui pembelajaran berbasis elearning. Pertama melalui menu atau fasilitas yang dapat digunakan untuk menyampaikan materi tentang kedisiplinan. materi dalam hal ini dapat berupa penjelasan maupun cerita atau kisah. Jenis kedua berupa praktik pembiasaan kedisiplinan. pada jenis kedua ini siswa tidak lagi diminta untuk menguasai teori namun sudah pada aspek mempraktikkan dan melakukan pembiasaan. Berdasarkan hasil pemetaan bahwa minimal terdapat empat nilai karakter kedisiplinan yang di dapat dikuatkan saat menggunakan sistem e-learning atau pembelajaran jarak jauh. Keempat karakter kedisiplinan tersebut adalah disiplin waktu, disiplin menegakkan aturan, disiplin sikap serta disiplin belajar
\end{abstract}

\section{Kata Kunci:}

e-learning, karakter kedisiplinan, pendidikan karakter, sekolah dasar.

\begin{abstract}
The digital era has penetrated in various lines of life, therefore education is also feasible to accelerate the development of internet-based learning innovations by prioritizing character education. The approach used in this research is content analysis. The formulation of the problem in this study are: a) How are the various e-learning facilities that can be used in distance learning in elementary schools, b) How are the various activities for strengthening character education in elementary schools that can be included in the various facilities available in e-learning. c) What are the various values of disciplinary character that can be implemented in Elementary School e-learning. This research is a content analysis research. The object of this research is a learning application based on the learning management system (LMS) google classroom and edmodo. The data collection method used is documentation and critical analysis instruments. The data sources are the results of the analysis and the results of FGDs with experts. The research data were processed using qualitative data. There are many similarities between the menus of LMS GC and Edmodo. Some of the menus contained in the two LMS are menus for providing material, assignment menus, quizzes, and discussion facilities. Based on the variety of e-learning facilities for strengthening character education, it can be concluded that there are two main characters of strengthening discipline character education through e-learning-based learning. First, through menus or facilities that can be used to convey material about discipline. The material in this case can be in the form of an explanation or a story or story. The second type is the practice of habituation of discipline. In this second type, students are no longer asked to
\end{abstract}


master the theory but are already in the aspect of practicing and making habituation. Based on the mapping results, there are at least four values of disciplinary character that can be strengthened when using elearning or distance learning systems. The four disciplinary characters are time discipline, discipline in enforcing rules, discipline in attitude and discipline in learning

Keywords:

e-learning, character discipline, character education, elementary school

\section{A. Pendahuluan}

Semenjak ditemukan teknologi internet, pertumbuhan ekosistem digital dan cloud computing semakin menyebar pada setiap lini masyarakat. Menurut data yang dirilis Asosiasi Penyelenggara Jasa Internet Indonesia (APJII) 2018, hampir tidak ada perbedaan signifikan antara jumlah pengguna internet di perkotaan dan pedesaan. Sebanyak $74 \%$ masyarakat urban mengakses internet, sedangkan masyarakat rural mencapai $61,6 \%$ (www.apjii.or.id). Hal tersebut mengindikasikan persebaran teknologi internet tidak terbatas pada aspek geografis. Persebaran teknologi internet yang sangat luas dapat dipastikan membawa dampak pada kehidupan masyarakat. Percepatan dalam penemuan ilmu pengetahuan dan teknologi menjadi salah satu dampak yang tidak terelakkan. Bahkan Junaidi memprediksi pekerjaan manusia di masa datang akan didominasi oleh penggunaan komputer dan internet (Apri Junaidi. 2015).

$$
\text { Percepatan }
$$

persebaran ekosistem digital salah satunya disebabkan peningkatan pengguna internet di setiap individu. Data APJII tahun 2018 menyebabkan terjadi peningkatan pengguna internet di tiap tahunnya. Pada tahun 2017 penetrasi pengguna internet di Indonesia sejumlah 143, 26 juta jiwa, atau 54, 68\% dari total populasi penduduk Indonesia. Tahun 2018 pengguna Internet meningkat menjadi
171, 17 Juta jiwa atau $64,8 \%$ dari total populasi penduduk Indonesia (www.apjii.or.id). Data tersebut menunjukkan adanya peningkatan yang cukup tinggi $(10,12 \%)$ pada pengguna internet tiap tahunnya. Persebaran penggunaan internet salah satunya disebabkan teknologi mobile yang juga tersebar secara pesat. Sesuai dengan hasil survey APJII 2018, Mobile phone menduduki posisi tertinggi pada perangkat yang digunakan oleh masyarakat untuk mengakses internet (www.apjii.or.id). Peta penggunaan internet tersebut menunjukkan peluang terus meningkatnya aktivitas masyarakat dengan internet di berbagai lini aktivitas.

Tren peningkatan pengguna dan akses internet oleh individu secara tidak langsung memicu peningkatan layanan institusi atau lembaga yang juga berbasis internet. Beragam aktivitas lembaga pemerintah maupun swasta terbukti telah mengimplementasikan aktivitas berbasis cloud computing dan internet untuk beberapa layanannya. Dalam aspek keragaman bidang, adopsi layanan berbasis internet juga telah menyebar berbagai aktivitas, mulai dari bidang transaksi, jasa transportasi, kesehatan hingga yang berbasis agama. Tidak disangkal lagi aspek transportasi telah banyak terwarnai dengan pola online, mulai dari pemesanan tiket online hingga taksi dan ojek online. Tidak hanya aspek jual beli dan transportasi, pada bidang agama beberapa lembaga telah menggunakan 
aplikasi zakat online guna meningkatkan efektivitas pembayaran zakat (Sakka, Rahman \& Qulub. 2019). Meningkatnya adopsi pemanfaatan internet ke berbagai lini kehidupan masyarakat tidak lepas dari tawaran banyaknya prinsip positif yang melekat pada teknologi internet tersebut. Setyawan menyebutkan bahwa terdapat enam faktor signifikan penentu adopsi cloud computing pada beberapa rumah sakit di Jawa Timur diantaranya yaitu kefaedahan, kemudahan penggunaan, kompleksitas, serta menjawab kebutuhan (Setyawan. 2016). Penelitian lain tentang transportasi ditemukan bahwa beberapa pertimbangan konsumen saat memilih transportasi online dari pada konvensional diantaranya adalah karena aspek kepraktisan, transparansi, kepercayaan, keamanan dan kenyamanan (Anwar. 2017). Data hasil penelitian tersebut mengindikasikan bahwa terdapat banyak memunculkan faktor positif baru pada tata kelola berbasis internet. Keseluruhan faktor tersebut mengarah pada peningkatan kualitas, efisiensi dan efektifitas layanan.

Pada aspek pendidikan, selain aspek kemudahan, salah satu yang mendukung efektifitas penggunaan internet dalam pembelajaran adalah karena adanya prinsip tidak terbatas ruang dan waktu yang melekat pada pembelajaran berbasis internet (Nadziroh. 2017). Belajar dimana saja dan kapan saja merupakan prinsip dasar pendidikan. Dengan keberadaan sistem pembelajaran berbasis internet, kondisi tersebut menjadi lebih mudah terealisasi. Peluang terjadinya belajar kapan saja dan dimana saja melalui elearning ini dapat terwujud karena ada dukungan big data dalam era cloud computing ini (Agustini. 2017).
Meskipun tidak dapat dipungkiri internet membawa dampak negatif, namun jika dikelola dengan baik maka tata kelola pembelajaran berbasis internet lebih membawa dampak positif daripada dampak negatif.

Banyaknya prinsip positif yang terdapat pada cloud computing menjadikan difusi inovasi pemanfaatan internet dalam pembelajaran sudah menjadi sebuah keniscayaan. Akselerasi bidang pendidikan dalam memanfaatkan internet dibanding dengan bidang lain sangat dibutuhkan. Jika sekolah tidak pernah mencoba mengoptimalkan internet sebagai sumber belajar, lambat laun perkembangan teknologi pasti akan memaksa pengguna untuk beradaptasi dengan perkembangan teknologi, diantaranya adalah internet. Siswa yang dihadapi oleh calon guru sekolah dasar saat ini adalah siswa SD yang sudah terbuka dengan dunia internet. Sebagaimana pengelompokan generasi yang diklasifikasikan oleh David dan Jonah Stillman, bahwa generasi yang lahir pasca tahun 1995 (disebut generasi Z) adalah generasi yang sangat terbuka dengan internet (Stillman \& Stillman. 2018). Oleh karenanya layak bagi pendidikan pada tingkatan sekolah dasar untuk lebih awal mengetahui pengaplikasian serta konsekuensi pembelajaran berbasis online.

Implementasi pendidikan karakter menjadi salah satu tantangan dalam masyarakat di era digital. Hasil penelitian Kurniawan dkk (2018) menyebutkan bahwa terdapat perbedaan antara persepsi dan implementasi pendidikan karakter di dunia maya. Dalam konteks bullying sebagai salah satu tindakan tidak berkarakter, lebih dari 95\% responden sepakat bahwa bullying adalah perilaku yang tidak berkarakter. Persepsi tentang 
tindakan bullying tersebut berkebalikan dengan aktivitas yang dialami oleh siswa. Banyak anak level sekolah dasar telah menjadi korban dan menjadi pelaku aktivitas bullying tersebut. Data penelitian tersebut menjadi salah satu referensi tentang tantangan penerapan penguatan pendidikan karakter khususnya bagi anak yang lahir di era digital (generasi Z).

Diera digital ini yang tetap tidak bisa ditinggalkan adalah aspek pendidikan karakter. Pembelajaran berbasis digital layak tetap mengedepankan pendidikan karakter. Salah satu tawaran implementasi pendidikan karakter berbasis pembelajaran digital adalah adanya integrasi penguatan pendidikan karakter dalam pembelajaran berbasis e-learning. Pendidikan karakter mempunyai kemampuan yang harus dikembangkan pada peserta didik melalui persekolahan yaitu berbagai kemampuan yang akan menjadikan manusia sebagai makhluk yang berketuhanan (tunduk patuh pada konsep ketuhanan) dan mengemban amanah sebagai pemimpin di dunia. Sedangkan tujuan pendidikan karakter adalah memfasilitasi penguatan dan pengembangan nilai-nilai tertentu sehingga terwujud dalam perilaku anak, baik ketika proses sekolah maupun setelah proses sekolah (setelah lulus dari sekolah). Pendidikan karakter juga mengoreksi perilaku peserta didik yang dikembangkan oleh sekolah (Kesuma , 2012:10).

Oleh karenanya integrasi pendidikan karakter pada implementasi pembelajaran berbasis digital menjadi tuntutan baru dengan kemajuan model pembelajaran. Dengan demikian urgensi (keutamaan) penelitian ini antara lain adalah:
1. Teridentifikasinya pendidikan karakter yang dapat diimplementasikan dalam pembelajaran di sekolah dasar.

2. Meningkatnya efektivitas penguatan nilai karakter setelah diterapkannya e-learning adaptif pada proses belajar mengajar yang sesungguhnya.

\section{B. Hasil dan Pembahasan}

\section{Ragam Fasilitas E-Learning Yang Dapat Digunakan Dalam Pembelajaran Jarak Jauh Di Sekolah Dasar}

\section{a. Ragam Fasilitas E-Learning Google Classroom \\ Google Classroom (GC) adalah} layanan web pembelajaran bersifat tidak berbayar, yang dikembangkan oleh Google untuk sekolah, yang bertujuan untuk menyederhanakan membuat, mendistribusikan, dan menilai tugas tanpa harus bertatap muka. Tujuan utama Google Classroom adalah untuk merampingkan proses berbagi file antara guru dan siswa. Secara terpisah namun masih dalam satu akun, Google Classroom juga dapat menggabungkan Google Drive untuk pembuatan dan pengiriman penugasan, Google Docs, Sheets, dan Slides untuk penulisan, Gmail untuk komunikasi, dan Google Calendar untuk penjadwalan. Siswa dapat diundang untuk bergabung dengan kelas melalui kode pribadi, atau secara otomatis diimpor dari domain sekolah.

Aplikasi GC seluler tersedia untuk perangkat iOS dan Android. Hal tersebut memungkinkan pengguna mengambil foto dan melampirkan penugasan, berbagi file langsung dari perangkat smartphone, tanpa harus membuka laptop atau komputer desktop. Guru dapat memantau kemajuan untuk setiap siswa, dan setelah dinilai, guru dapat kembali 
bekerja bersama dengan melalui komentar.

Untuk masuk atau bergabung ke kelas, siswa dapat menggunakan dua cara. Pertama dengan memasukkan kode kelas yang sebelumnya telah dibagikan oleh pendidik, seperti: edxowl2. Kedua dengan cara menyalin link undangan yang sebelumnya telah dibagikan oleh pendidik. Setelah memasukkan kode kelas, Siswa dapat masuk secara individual oleh masingmasing siswa atau menyalin link yang diberikan, maka tampilan beranda google classroom akan muncul kelas yang diikuti sesuai dengan judul dan tampilan yang dibuat oleh pendidik sebelumnya.

Google Classroom terdiri dari 4 bagian: Stream (Forum), Classwork (Tugas Kelas), People (Anggota), dan Grades (Nilai). Bagian pertama, Forum atau Stream adalah halaman aktivitas yang menampilkan Pengumuman, Pertanyaan (diskusi), Materi (Bahan Pengajaran) dan Tugas yang diberikan guru. Di halaman ini, guru dan siswa bisa langsung saling berinteraksi. Platform ini terintegrasi dengan email, sehingga setiap interaksi (meskipun hanya komentar yang membalas komentar kita) maupun segala informasi dan aktivitas pendidik akan memberikan notifikasi email kepada siswa. Bagian kedua, Classwork (Tugas Kelas) adalah halaman yang digunakan untuk membuat tugas atau membuat materi pengajaran. Bagian Ketiga, People (Anggota), berisikan semua nama- nama yang masuk ke kelas tersebut baik sebagai pendidik maupun anggota/ siswa. Bagian Keempat, Grades atau Nilai adalah halaman untuk mengatur penilaian dari setiap tugas yang diberikan.

\section{b. Ragam Fasilitas E-Learning Edmodo}

Edmodo merupakan sebuah platform pembelajaran yang dapat digunakan oleh pendidik dalam menyampaikan materi kepada peserta didik. Seperti platform belajar lainnya, edmodo memiliki beberapa fitur menarik yang dapat dijadikan sebagai solusi untuk menunjang kebutuhan pembelajaran jarak jauh. Disamping itu edmodo juga dikategorikan sebagai jejaring sosial khusus pembelajaran. Hal ini dikarenakan fitur yang ditampilkan seperti fitur pada aplikasi twitter.

Aplikasi edmodo dapat diakses melalui smartphone atau laptop dengan catatan terhubung dengan koneksi internet. Untuk memulai pembelajaran, pengguna akan diarahkan untuk membuat akun terlebih dahulu yang meliputi 3 (tiga) kategori seperti guru, murid, atau orang tua. Adapun data yang perlu dalam membuat akun meliputi email dan identitas pribadi.

Banyak orang memilih menggunakan aplikasi edmodo dalam pembelajaran karena dinilai mampu memberikan pengalaman belajar yang lebih berkesan. Beberapa fitur yang dapat digunakan pada aplikasi Edmodo meliputi:

1) Parent Code. Selain Guru dan peserta didik, aplikasi edmodo juga memiliki fitur yang memungkinkan orang tua ikut serta dalam mengikuti kelas, melacak nilai, dan mengetahui kegiatan yang akan atau yang sedang berlangsung.

2) Award Badge. Pada fitur ini guru dapat memberikan penghargaan kepada peserta didik yang mampu menyelesaikan tugas. 
3) Polling. Fitur ini diberikan agar guru dapat dengan mudah respon peserta didik terkait materi atau tugas yang diberikan.

4) Assignment. Pada fitur ini guru dapat memberikan materi kepada peserta didik dengan berbagai format seperti file, dokumen, link, vidio, dan audio. Fitur ini merupakan fitur utama pada aplikasi edmodo. Peserta didik yang sudah mempelajari materi dari guru dapat langsung mengerjakan lalu mengumpulkan dengan fitur mengunggah file.

5) Gradebook. Fitur ini diperuntukan bagi guru untuk memetakan nilai secara otomatis.

6) Quiz. Pada fitur ini guru dapat melakukan evaluasi pembelajaran melalui quiz.

7) Library. Fitur ini dapat digunakan untuk kepentingan menyimpan berbagai macam referensi seperti jurnal, buku dan lain-lain.

Berdasarkan ragam fasilitas yang terdapat pada GC dan Edmodo, terdapat beberapa kesamaan menu/fasilitas. beberapa menu yang secara esensial terdapat di kedua platform tersebut adalah:

1) Fasilitas pemberian materi. pada fasilitas ini baik GC maupun Edmodo sama-sama memiliki menu khusus. materi dapat berupa teks, audio, video maupun multimedia.

2) Fasilitas pemberian tugas. Baik pada GC maupun edmodo keduanya terdapat menu pemberian tugas. Kesamaan lain dalam pemberian tugas ini adalah sama-sama terdapat menu pemberian tenggat waktu pengumpulan tugas. Tenggat waktu yang dimaksud adalah laman pengumpulan tugas dapat secara otomatis tertutup (closed) pada tenggat waktu yang telah ditentukan.

3) Fasilitas pemberian ruang diskusi. Kedua platform memiliki ruang diskusi untuk peserta didik mendiskusikan materi yang diberikan.

4) Pengaturan sistem kelas. Kedua platform memiliki pengaturan apakah kelas dibuat terbuka atau tertutup. Terbuka dalam arti siswa dapat keluar masuk kelas dengan bebas, atau siswa manapun bisa masuk kelas tanpa harus tau kode kelas atau tanpa harus seizin guru/instruktur. kelas tertutup dalam arti kelas hanya disetting khusus, bagi siswa yang menghendaki masuk harus tahu kode kelas atau seizing guru. Jika kelas sudah ditutup oleh sistem, maka siswa tidak lagi bisa masuk kelas kecuali seizin guru.

Selain empat fasilitas yang menjadi kesamaan antara GC dan Edmodo, terdapat satu menu yang secara teknis tidak sepenuhnya samasama terintegrasi, namun secara prinsip sama-sama dapat diintegrasikan, yaitu menu kuis. Kuis pada platform Edmodo terintegrasi di dalam platform secara langsung. Kuis pada GC tidak secara langsung berada dalam sistem GC, namun kusi dapat diproduksi menggunakan fasilitas Google yang lain yaitu Google Form. 
Setelah kuis dikembangkan oleh guru menggunakan Google Form ini, selanjutnya dapat diintegrasikan dalam salah satu menu di GC. Kesamaan karakter kuis pada kedua platform ini adalah a) setelah mengerjakan kuis, peserta didik dapat langsung melihat perolehan skor hasil kerjanya, b) Pada Aktivitas kuis dapat dilakukan pengaturan waktu berapa lama kuis akan selesai.

\section{Ragam Aktivitas dalam e- learning sebagai Penguatan Pendidikan Karakter Kedisiplinan di SD}

Berdasarkan ragam aktivitas elearning dalam platform Google Classroom dan Edmodo, terdapat beberapa fasilitas serta aktivitas pembelajaran secara online yang dapat digunakan sebagai sarana penguatan pendidikan karakter kedisiplinan siswa. Pada penelitian ini indikator kedisiplinan diambil dari parameter yang dikeluarkan oleh Asmani (2015: 94) bahwa kedisiplinan dapat diukur dari disiplin waktu, disiplin menegakkan aturan, disiplin sikap dan disiplin dalam beribadah. Dalam konteks pembelajaran, penelitian ini menggunakan teori dari Juliandi (2014:3) yang mengkategorikan disiplin dalam belajar menjadi empat aspek beserta indikatornya. Keempat aspek disiplin belajar menurut Juliandi adalah 1) Ketaatan terhadap tata tertib sekolah, 2) Ketaatan terhadap kegiatan belajar di sekolah, 3) Ketaatan dalam mengerjakan tugas-tugas pelajaran, dan 4) Ketaatan terhadap kegiatan belajar di rumah. Dalam kondisi pandemic Covid19 ini diberlakukan Belajar Dari Rumah (BDR). Pada aktivitas BDR ini aspek kedisiplinan yang disampaikan oleh Juliandi pada poin ketiga dan keempat menjadi tidak ada perbedaan signifikan karena tugas-tugas pembelajaran (poin tiga) juga dilakukan bersamaan dengan kegiatan belajar di rumah (poin empat). Oleh karenanya dalam penelitian ini kategori kedisiplinan belajar pada penelitian ini mengerucut menjadi tiga kategori.

Hasil analisis tentang platform elearning menyebutkan terdapat beberapa menu yang potensial untuk digunakan sebagai penguatan pendidikan karakter. Berikut beberapa menu dalam pembelajaran berbasis elearning yang berpotensi digunakan sebagai penguatan pendidikan karakter. Pertama, fasilitas/menu pemberian materi. Fasilitas ini dapat digunakan sebagai sarana penyampaian konten materi dan bahan-bahan baik secara verbal, audio maupun visual tentang nilai-nilai pendidikan karakter. Fasilitas ini perannya sama dengan sumber belajar by design lain yaitu pendidikan karakter sebagai kontennya, sedangkan LMS sebagai media pembukus materi pembelajarannya.

Kedua, fasilitas pemberian tugas. Pada fasilitas ini guru dapat mendesain praktik kedisiplinan dengan cara menegakkan tenggat waktu pengumpulan tugas. Pada fasilitas ini siswa tidak lagi belajar kedisiplinan melalui teori. Melalui tenggat waktu yang ditentukan untuk pengumpulan tugas, peserta didik langsung praktik menerapkan dan membiasakan kedisiplinan. Dalam konteks kedisiplinan belajar, tenggat waktu pengumpulan tugas yang disetting secara langsung oleh sistem dapat digunakan untuk menguatkan ketaatan dalam mengerjakan tugas-tugas sekaligus ketaatan dalam belajar di rumah.

Ketiga, fasilitas diskusi. Melalui fasilitas diskusi yang ada di e-learning, guru juga dapat mempraktikkan dan 
membiasakan kedisiplinan siswa. Adapun cara dan pendekatannya adalah melalui ketentuan dan aturan main diskusi yang harus dilakukan oleh Peserta didik. Selain melalui penegakan aturan tentang praktik diskusi, pembiasaan kedisiplinan melalui forum diskusi juga dapat diterapkan terkait kedisiplinan sikap. Guru dapat melatih peserta didik bersikap secara bijak dan sopan dalam berdiskusi, diantaranya saat berbicara dan bertutur kata meskipun dalam dunia maya. Dalam konteks kedisiplinan belajar, penegakan aturan dalam diskusi menjadi salah satu bentuk penguatan ketaatan terhadap tata tertib sekolah.

Keempat, fasilitas pengaturan sistem kelas. Menu setting kelas dalam LMS memberikan peluang bagi guru untuk mengatur kelas menjadi pola tertutup. Saat memulai pembelajaran, setiap siswa diberikan batas waktu untuk masuk menggunakan kode yang disediakan. Jika melebihi batas waktu yang diberikan siswa bisa mendapatkan teguran. Hal ini dapat digunakan sebagai sarana penguatan praktik kedisiplinan waktu dan penegakan aturan.

Berdasarkan ragam fasilitas elearning untuk penguatan pendidikan karakter ini dapat disimpulkan bahwa terdapat dua karakter utama penguatan pendidikan karakter kedisiplinan melalui pembelajaran berbasis elearning. Pertama melalui menu atau fasilitas yang dapat digunakan untuk menyampaikan materi tentang kedisiplinan. materi dalam hal ini dapat berupa penjelasan maupun cerita atau kisah. Jenis kedua berupa praktik pembiasaan kedisiplinan. pada jenis kedua ini siswa tidak lagi diminta untuk menguasai teori namun sudah pada aspek mempraktikkan dan melakukan pembiasaan.

\section{Ragam Nilai-Nilai Karakter Kedisiplinan yang Dapat Diimplementasikan Dalam E- Learning di SD}

Berdasarkan pemetaan tentang ragam nilai karakter kedisiplinan yang dapat diajarkan dan diimplementasikan pada pembelajaran berbasis e-learning yaitu:

a. Disiplin waktu.

Integrasi penanaman karakter kedisiplinan melalui e-learning dapat dilakukan melalui aktivitas pemberian tugas dan kuis yang disertai tenggat waktu. Pemberian tenggat waktu dari setiap tugas dan juga kuis merupakan bentuk praktik serta pembiasaan kedisiplinan yang dilakukan oleh guru untuk peserta didiknya. Adapun menu dalam LMS yang dapat digunakan oleh guru untuk memfasilitasi kegiatan ini adalah menu diskusi, menu kuis juga menu pengaturan kelas.

Terkait disiplin waktu, secara khusus melalui Al-Qurean surat AlAshr: ayat 1-3, Allah swt berfirman tentang pentingnya disiplin menghargai waktu untuk bekerja baik bekerja untuk kepentingan duniawi maupun untuk kepentingan ukhrowi (Ayatullah (2020: 224). Dalam konteks pembelajaran, ketepatan waktu menjadi salah satu indikator yang mencerminkan kontribusi siswa dalam disiplin belajar (Sari dan Hadijah (2017:235). Oleh Karenanya disiplin waktu menjadi salah satu aspek terpenting dalam penanaman karakter kedisiplinan pada peserta didik di sekolah dasar dalam pembelajaran online.

b. Disiplin menegakkan aturan atau tata tertib. 
Integrasi penanaman karakter kedisiplinan menegakkan aturan dapat dilakukan untuk beberapa aktivitas pembelajaran melalui elearning. Diantara aktivitas tersebut adalah penegakan aturan berdiskusi, aturan presensi dan aturan pengerjaan dan pengumpulan tugas serta aturan lain yang dibuat untuk berbagai aktivitas pembelajaran berbasis e-learning. Adapun menu dalam LMS yang dapat digunakan oleh guru untuk memfasilitasi kegiatan penegakan aturan atau tata tertib ini diantaranya adalah menu diskusi, menu pengumpulan tugas, serta menu berinteraksi secara online. Selain menu diskusi pada dasarnya semua menu pembelajaran dalam LMS secara umum dapat disertai aturan main.

Aturan main menjadi tata tertib peserta didik dalam melaksanakan pembelajaran daring. Hal ini sesuai dengan hasil penelitian Yuliantika (2017:42) yang menyebutkan bahwa faktor yang paling dominan mempengaruhi disiplin belajar siswa adalah penerapan tata tertib sekolah. Hal ini dikuatkan oleh hasil penelitian Ayatullah (2020: 225) supaya proses pembelajaran berlangsung kondusif maka sekolah harus mempunyai tata tertib. Oleh Karenanya pembelajaran, baik luring maupun daring, bijaknya terdapat tata tertib yang berlaku dengan tujuan selain untuk menjaga kondusifitas pembelajaran juga untuk menanamkan nilai karakter disiplin pada siswa.

c. Disiplin sikap.

Integrasi penanaman karakter kedisiplinan bersikap dapat dilakukan melalui sikap dalam melakukan diskusi, khususnya sikap dalam bertutur di dunia maya.
Adapun menu dalam LMS yang dapat digunakan oleh guru untuk memfasilitasi kegiatan ini diantaranya adalah menu diskusi termasuk diantaranya adalah menu chat yang berfungsi untuk komunikasi langsung antara peserta didik dengan guru. Disiplin sikap salah satunya adalah untuk membentuk sikap, penampilan dan tingkah laku peserta didik sesuai dengan tatanan nilai, norma, dan ketentuan-ketentuan yang berlaku di sekolah dan dimanapun mereka berada (Mustari: 2014). Oleh Karenanya, kedisiplinan bersikap dalam bertutur di dunia maya menjadi salah satu poin penting dalam penguatan pendidikan karakter di sekolah dasar di era digital agar terbentuk disiplin berkomunikasi secara baik dan bijak, baik secara langsung terlebih di dunia maya.

d. Disiplin Belajar.

Pada aktivitas disiplin belajar online atau belajar dari rumah terdapat tiga aspek yang membangun dan menjadi ciri disiplin belajar. Aspek pertama, yaitu aspek ketaatan terhadap tata tertib. Pada aspek ini guru dapat memanfaatkan penegakan aturan belajar online sebagai sarana penanaman dan penguatan karakter kedisiplinan. Aspek kedua, yaitu aspek ketaatan terhadap kegiatan belajar di sekolah. Beberapa fasilitas atau menu pada pembelajaran online menggunakan LMS untuk implementasi aspek ke dua ini adalah menu diskusi, tugas dan kuis. Aspek ketiga dan keempat adalah aspek ketaatan dalam pengerjaan tugas-tugas dan ketaatan terhadap kegiatan belajar di rumah. Untuk implementasi aspek ketiga ini guru dapat memanfaatkan menu 
penugasan (assignment) dam menu diskusi online.

Keseluruhan komponen pembelajaran online yang digunakan dalam menanamkan disiplin belajar online membutuhkan pengelolaan aturan, pengelolaan waktu hingga pengelolaan pola aktivitas. Pengelolaan tersebut salah satu tujuannya adalah terwujudnya manajemen kelas online atau belajar jarak jauh. Berdasarkan hasil penelitian Sari dan Hadijah (2017:233) bahwa terdapat pengaruh yang signifikan manajemen kelas terhadap disiplin belajar siswa, artinya disiplin belajar siswa dapat ditingkatkan melalui manajemen kelas yang dilakukan oleh guru.

Berdasarkan analisis diatas dapat disimpulkan bahwa minimal ada empat nilai karakter kedisiplinan yang di dapat dikuatkan saat menggunakan sistem elearning atau pembelajaran jarak jauh. Keempat karakter kedisiplinan tersebut ialah disiplin waktu, disiplin menegakkan aturan, disiplin sikap serta disiplin belajar.

\section{Simpulan}

Terdapat banyak kesamaan menu pada LMS GC dan Edmodo. Beberapa menu yang terdapat di kedua LMS tersebut adalah menu pemberian materi, menu penugasan, kuis, serta fasilitas diskusi. Berdasarkan ragam fasilitas e-learning untuk penguatan pendidikan karakter ini dapat disimpulkan bahwa terdapat dua karakter utama penguatan pendidikan karakter kedisiplinan melalui pembelajaran berbasis elearning. Pertama melalui menu atau fasilitas yang dapat digunakan untuk menyampaikan materi tentang kedisiplinan. materi dalam hal ini dapat berupa penjelasan maupun cerita atau kisah. Jenis kedua berupa praktik pembiasaan kedisiplinan. pada jenis kedua ini siswa tidak lagi diminta untuk menguasai teori namun sudah pada aspek mempraktikkan dan melakukan pembiasaan. Berdasarkan hasil pemetaan bahwa minimal terdapat empat nilai karakter kedisiplinan yang di dapat dikuatkan saat menggunakan sistem e-learning atau pembelajaran jarak jauh. Keempat karakter kedisiplinan tersebut adalah disiplin waktu, disiplin menegakkan aturan, disiplin sikap serta disiplin belajar

\section{Daftar Pustaka}

Agustini, Ketut. Inovasi teknologi dalam pendidikan melalui big data analytic dan personal learning. Prosiding Seminar Nasional Pendidikan Teknik Informatika. Bali, o9 September 2017. Hal: 10-14

Anwar, Ahsani Amalia. Online Vs Konvensional: Keunggulan dan konflik antar moda transportasi di Kota Makassar. ETNOSIA: Jurnal Etnografi Indonesia. Vol.2 No.2 (2017). Hal. 220-246

Apri Junaidi. Internet of things, sejarah, teknologi dan penerapannya. JITTER Jurnal Ilmiah Teknologi Informasi Terapan. Vol. 1 No. 3 (2015). Hal: 62-66.

Asmani, J. M. (2015). Tips Menjadi Guru Inspiratif, Kreatif dan Inovatif Yogyakarta: Diva Press

Asosiasi Penyelenggara Jasa Internet Indonesia. Penetrasi dan profil perilaku pengguna internet Indonesia. https://www.apjii.or.id/ (diakses pada o6 Juli 2019)

Ayatullah. 2020. Pendidikan Kedisiplinan Siswa Madrasah Aliyah. Pandawa: Jurnal Pendidikan dan Dakwah. Volume 2, Nomor 2. hal. 218-239 
Juliandi, Y. (2014). "Pengaruh Disiplin Belajar Terhadap Hasil Belajar Siswa Pada Mata Pelajaran Ekonomi SMAS Taman Mulia". Artikel Penelitian. Pontianak: Universitas Tanjungpura.

Mustari, Muhammad. 2014. Manajemen Pendidikan. Jakarta: Raja Grafindo Persada.

Nadziroh, Faridatun. Analisa efektifitas sistem pembelajaran berbasis elearning. Jurnal Ilmu Komputer dan Desain Komunikasi Visual. Vol. 2 No. 1 (2017). Hal: 1-14

Sakka, Abdul Rahman \& Qulub, Latiful. Efektifitas penerapan zakat online terhadap peningkatan pembayaran zakat pada lembaga Dompet Dhuafa Sulsel. Al-Azhar Journal of Islamic Economics. Vol. 1 No. 2 (2019) hal: 66-83
Sari, Bella Puspita \& Hadijah, Hady Siti. 2017. Meningkatkan kedisiplinan siswa melalui manajemen kelas. Jurnal Pendidikan Manajemen Perkantoran. Vol. 2 No. 2, Hal. 233241.

Stillman, D \& Stillman, J. Generasi Z memahami karakter generasi baru yang akan mengubah dunia kerja. Cetakan ketiga. Jakarta: Gramedia Pustaka Utama. 2018.

Yuliyantika, Siska. 2017. Analisis FaktorFaktor Yang Mempengaruhi Disiplin Belajar Siswa Kelas X, XI, dan XII di SMA Bhakti Yasa Singaraja Tahun Pelajaran 2016/2017. Jurnal Pendidikan Ekonomi Undiksha. Volume 9 No.1 hal. 35-44 